\title{
SOME REMARKS ON THE DIVERGENCES IN THE NARRATIVE OF GEORGE AKROPOLITES AND THEODORE SKOUTARIOTES ${ }^{1}$
}

\author{
Bojana D. Pavlović \\ Institute for Byzantine Studies of the Serbian Academy of Sciences and Arts, Belgrade, Republic of Serbia
}

\begin{abstract}
This paper deals with the differences between the texts of the two main sources for the $13^{\text {th }}$-century

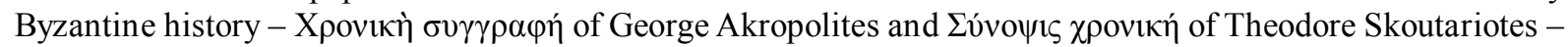
who give an account of the events from 1204 to 1261. The Chronicle of Theodore Skoutariotes relies on the historical work of George Akropolites to a great extent, although significant additions to or omissions from Akropolites' narrative can be noticed. The greatest divergence from the text of Akropolites is in the portrayal of the Laskarid emperors and the first Palaiologos, Michael VIII. Skoutariotes expressed positive attitude towards the Laskarids in the praises of their imperial virtues. In respect to Michael VIII, however, Skoutariotes tended to mitigate the excessive commendation of Akropolites by omitting certain epithets, or, by a careful word play that sometimes resulted in completely opposite statements compared with the ones we find in Akropolites. The differences in the accounts of the two writers can be explained by Skoutariotes' employment of other sources, unknown to us today, and also by the fact that he included his eye-witness account in the Chronicle he compiled. The additional details provided by Skoutariotes are corroborated with the information we find in other surviving sources, a fact which gives his testimony much more significance than previously believed. Apart from that, the author rises an important question of the employment of Skoutariotes' Chronicle by later historians. The article consists of the following sections: Introduction; George Akropolites and Theodore Skoutariotes. Their works; Methodology; Results and general remarks; as well as Divergences concerning the reign of Theodore I Laskaris (1205-1221); John III Vatatzes (1221-1254), Theodore II Laskaris (1254-1258); Michael VIII Palaiologos (1259-1282); and Conclusion.
\end{abstract}

Key words: George Akropolites, Theodore Skoutariotes, history of Byzantium, Chronicle, Laskarids, Michael VIII Palaiologos.

Citation. Pavlović B.D. Some Remarks on the Divergences in the Narrative of George Akropolites and Theodore Skoutariotes. Vestnik Volgogradskogo gosudarstvennogo universiteta. Seriya 4. Istoriya. Regionovedenie. Mezhdunarodnye otnosheniya [Science Journal of Volgograd State University. History. Area Studies. International Relations], 2019, vol. 24, no. 6, pp. 150-172. DOI: https://doi.org/10.15688/jvolsu4.2019.6.13

УДК 94“12”:930

ББК 63.3(0)4-93

Дата поступления статьи: 13.09.2019 Дата принятия статьи: 11.11.2019

\section{НЕКОТОРЫЕ ЗАМЕЧАНИЯ К РАСХОЖДЕНИЯМ В НАРРАТИВЕ ГЕОРГИЯ АКРОПОЛИТА И ФЕОДОРА СКУТАРИОТА ${ }^{1}$}

\author{
Бояна Драган Павлович \\ Институт византийских исследований, Сербская Академия наук и искусств, г. Белград, Республика Сербия
}

Аннотация. Исследование нацелено на анализ различий между текстами двух основных источников по

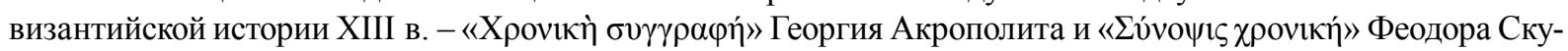
тариота. Обе хроники описывают события 1204-1261 годов. «Хроника» Феодора Скутариота опирается на исторический труд Георгия Акрополита. Следуя ему, Феодор Скутариот охватывает обширный период истории Никейской империи и последующих лет. Он делает значительные добавления или пропуски. Наиболее значимым различием двух исторических трудов оказывается изображение императоров династии Ласкаридов и первого Палеолога - Михаила VIII. Положительное отношение к Ласкаридам Феодор Скутариот выразил в похвалах их императорских добродетелей. Однако относительно Михаила VIII Феодор Скутариот стре- 
мится удержаться от непомерных восхвалений, характерных для Георгия Акрополита. Феодор Скутариот отказывается от использования некоторых эпитетов, или, играя словами, добивается прямо противоположного эффекта своих высказываний в сравнении с «Хроникой» Георгия Акрополита. Различия в изложении исторических событий у двух писателей могут отчасти объясняться использованием отличных, не дошедших до сегодняшнего дня, источников. Сыграл свою роль тот факт, что Феодор Скутариот являлся очевидцем некоторых описываемых им в его «Хронике» событий. Другие сохранившиеся источники позволяют увидеть особую значимость свидетельств Феодора Скутариота о разных событиях, которая в историографии явно недооценена. Важен и интересен вопрос об использовании «Хроники» Феодора Скутариота византийскими историками последующего времени.-Статья состоит из разделов «Введение», «Георгий Акрополит и Феодор Скутариот. Их труды», «Методология», «Результаты и общие замечания», в том числе разделы «Расхождения, касающиеся правления Феодора I Ласкариса (1205-1221)», «Иоанн III Ватаци (1221-1254)», «Феодор II Ласкарис (1254-1258)», «Михаил VIII Палеолог (1259-1282)», и «Заключение».

Ключевые слова: Георгий Акрополит, Феодор Скутариот, история Византии, хроника, Ласкариды, Михаил VIII Палеолог.

Цитирование. Павлович Б. Д. Некоторые замечания к расхождениям в нарративе Георгия Акрополита и Феодора Скутариота // Вестник Волгоградского государственного университета. Серия 4, История. Регионоведение. Международные отношения. - 2019. - Т. 24, № 6. - С. 150-172. - (На англ. яз.). - DOI: https://doi.org/ 10.15688/jvolsu4.2019.6.13

\section{Introduction}

A lot of pages have been dedicated to Byzantine historiography and its characteristics only to conclude that each work has its own features and that each writer is unique, no matter how minor his writing may seem at first glance [36]. Certainly, there exist common places and common elements since the works stem from the same culture and were intended for an audience (we refer to the educated elite) that shared the same intellectual views as the writers [10]. This being said it is obvious that challenges of dealing with Byzantine historiography do not seize to exist. They are rather augmenting, enhancing the will of the researchers to dive deep below the surface of the text and strive for the unanswered questions, or better yet, for the unasked questions that will provide new and unexplored paths for further research. When it comes to the $13^{\text {th }}$ century, Byzantine history challenges come from the mere fact that there existed two strong political currents, pro- and anti- Palaiologan that dictated the tone of the historiographical works of the period. Complex political, social and ecclesiastical issues were treated from different angles and have come down to us in the form of opposing historical texts. Further research on this subject, as well as new methodological approaches are being explored [32]. Even though it is certain that we do not possess all of the sources for the period in question we have just about enough information to get the general idea of how conflicting these two parties were. In the light of the above mentioned in this paper we shall analyze the main narrative sources for the history of the so-called "Byzantine Empire in Exile", i. e. Nicaean Empire, the works of George Akropolites and Theodore Skoutariotes. Although the two texts may seem quite similar at first glance, there are serious and non-negligible differences. This has firstly been noted by A. Heisenberg who dealt with Skoutariotes' additions and divergences to the text of Akropolites [20, S. 277-302]. A valuable Russian translation of these additions was later made by P.I. Zhavoronkov [1, c. 315-336]. (For the differences between the Russian and English translation cf. [5]). As opposed to the work of Akropolites, which has been thoroughly analyzed $[1 ; 16]$ (See: $[29$, S. 442-447, 477-478; 66, б. 3259]), Skoutariotes' Chronicle has been unrightfully disregarded in the past. Apart from A. Heisenberg, very few scholars have paid more attention to this Chronicle [3]. However, modern Byzantinists have paid much more attention to this work realizing its importance $[55 ; 56 ; 57 ; 63]$. And its importance lies precisely in the divergence from the text of Akropolites. The most significant difference rests in the portrayal of the Laskarid emperors (especially John III Vatatzes and Theodore II Laskaris) and the first Palaiologan emperor, Michael VIII. Therefore, it is the goal of this paper to carry out a more thorough analysis of these differences, as well as to pose a few questions with respect to the purpose of their composition and the audience they were intended 
for. Before we go into further inquiry chief information about the two writers and their works should be provided.

\section{George Akropolites and Theodore Skoutariotes. Their works}

George Akropolites was born in an aristocratic family, in Constantinople, most probably around $1217[16$, p. 6 , n. $13 ; 46$, no. 518 ; 51, p. 49]. His social and political engagement began in Nicea, the capital city of the "Empire in Exile", at the court and in the service of the emperor John III Vatatzes. Akropolites was also educated at the imperial court along with several of his peers and future emperor's servants. $\mathrm{He}$ attended the classes of the most learned men of his time, Nikephoros Blemmydes and Theodore Hexapterigos [16, p. 8-9]. Akropolites was subsequently entrusted with the education of the heir to the throne, Theodore II Laskaris (12541258). Good relations between the student and his teacher, testified in the correspondence of the two intellectuals [53], were disrupted after Theodore II's rise to power and due to the emperor's illness which Akropolites informs us of $^{2}$. Further engagement and rise in status Akropolites continued as "megas logothetes" of the Laskarids and also under Michael VIII Palaiologos (1259-1282), with whom he was in family relations through his wife Eudokia, the emperor's cousin ${ }^{3}$. It is assumed that Akropolites got the title of megas logothetes as early as 1255 from the emperor Theodore II Laskaris [16, p. 22 23]. As "megas logothetes" Akropolites was ordered to travel to Lyons where, in 1274, he signed a document proclaiming the union of the Churches. The clash with the Arsenites, the followers and supporters of the patriarch Arsenios and fierce opponents of the policy of Michael Palaiologos, ensued in which George Akropolites also had an important share $[16$, p. $14-16 ; 18$, p. 409.26-411.2]. The great logothetes of Michael VIII died in 1282, the year when the emperor, whom he had served for nearly thirty years, also passed away [16, p. 16].

The work of George Akropolites, Xроviкทे

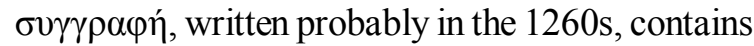
a detailed but very biased portrayal of the events in the Nicaean Empire with an emphasis on military and political history [29, S. 442-446]. (About the time of the creation of the work cf. [16, p. 31-34]). It gives an account of the affairs starting from 1204, the fall of Constantinople to the Latins, and ends abruptly in 1261, right after the description of Michael VIII's triumphal entry into the Queen of the cities. Akropolites' work is mostly distinguished by the negative description of the emperors of the Laskarid dynasty while his positive hero and, thus, one of the leading characters of his work, is Michael VIII Palaiologos. The role of the most negative hero of Akropolites' work was given to the emperor Theodore II Laskaris, either because of the personal animosity of the historian towards the son and successor of John III Vatatzes [16, p. 29$34,39-41]$, or due to the fact that Akropolites, with such a hostile portrayal of Theodore II, wanted, in fact, to emphasize the positive character and virtue of Michael VIII. It should

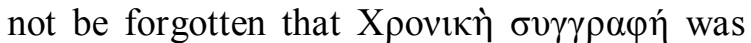
written during his reign and in the City recaptured by the Byzantines in the time of the first Palaiologan emperor. Akropolites' work was a program history, a fact that can be supported by Michael VIII's own statements. Namely, in the typicon for the Monastery of St. Demetrios of the Palaiologoi-Kelibara in Constantinople the emperor says: "As to how the members of the family placed the prosperity to be found here below second to their concern about living in a manner pleasing to God which would lead them to inherit the life hidden in Him (God. - B. P.), we shall refer (the reader. $-B$. P.) to the discourses and books composed by the learned. For these give an account not only of their dignities and honors, the great influence they had with rulers, and how they accumulated vast riches, no less of their combat in wartime, their generalship, and their valor, but they also inform us of their erection of religious houses, holy convents and monasteries, their donation of property, their aid to the poor, their concern for the infirm, and their protection of the indigent of all sorts, and all their pious deeds which bore fruit before God" [30, p. 449] (Also see [8, p. 1242]). Of these learned men who wrote about the Palaiologan family members practically nothing is known, but it is possible that the emperor referred, among others, to Niketas Choniates, who mentions some of the emperor's family members in his History, and 
Jacob, the archbishop of Ochrid, who dedicated several poems to the memory of Michael VIII's father Andronikos. Ultimately, the emperor could have also referred to the work of George Akropolites, who started writing before the typicon was issued [8, p. 1240, n. 1]. Therefore, it would not be wrong to assume that the emperor instigated his megas logothetes to write the history of his reign. It is clear that the chief object of Akropolites' work was to deal with Michael's rise to power. His work ends suddenly, with the year 1261 , therefore, there is no mention of significant but controversial matters related to Michael's coming to the throne. George Akropolites, an eyewitness and a participant in the events, does not provide any information on blinding of John IV Laskaris, a legitimate heir to the throne. Interesting enough, his History does not even reach the point of discussing the Church matters. Therefore, it can only be speculated about the reasons for, as it seems to us today, the abrupt end of the work. It should not be completely ruled out, however, that the work of megas logothetes had a continuation, unknown to us today, for it has been established that some of his works were burnt at the Council of Blachernae in $1283^{4}$. It was at that time that the part of his History, which could have dealt with the later years of the reign of Michael Palaiologos, above all with his coronation in Constantinople and the negotiations with the papacy, could have been burnt ${ }^{5}$. If, indeed, Akropolites' History dealt with the later events, why is it that his close follower Skoutariotes, clearly a sympathizer of the Laskarid party, also ended his Chronicle with the year 1261, since it is assumed that he compiled his work in the late 1280s? Be that as it may, the fact remains that the "sin" of Michael Palaiologos, committed at the very beginning of his reign - the blinding and removal of the son and successor of Theodore II, John IV Laskaris, from the throne - is completely omitted from both works. In this way the rise and renewal of the Empire under Michael VIII Palaiologos - the main theme of Akropolites' History - was immortalized, although, based on the account of Skoutariotes, it is clear that the restoration of the Empire began even before his time, in the time of the Laskarid emperors. It does not escape notice, though, that both of the works in question represent a counterbalance to the History of Niketas Choniates which dealt with the decline and fall of the Empire, the corruption of its rulers and decay of moral integrity of its inhabitants [50].

Not much is known about the personality of Theodore Skoutariotes [52, p. 1912-1913]. It is assumed that he was born at the end of the first half of the $13^{\text {th }}$ century. Theodore Skoutariotes was "ó $\dot{\varepsilon} \pi \mathrm{i} \tau \tilde{\omega} v \delta \varepsilon \eta \dot{\sigma} \sigma \varepsilon \omega v$ " ("the one in charge of the petitions"), he became dikaiophylax in May 1270 and afterwards " $\sigma \alpha \kappa \varepsilon \lambda \lambda$ íov $\tau \tilde{\eta} \varsigma \mu \varepsilon \gamma \alpha \dot{\alpha} \lambda \eta \varsigma \varepsilon \kappa-$ $\kappa \lambda \eta \sigma i ́ \alpha \varsigma$ ". By 1277 Theodore Skoutariotes was already hypertimos and finally, after having signed the acceptance of the Union ${ }^{6}$, he was appointed Metropolitan of Kyzikos by Michael VIII. Morever, Theodore Skoutariotes was one of the ambassadors to the papal court together with the imperial officials and unionist supporters George Metochites and Constantine Meliteniotes [54, S. 64-65]. (Also see: [55, S. 551, Anm. 3]). Skoutariotes was removed from his position in 1283 upon the arrival of the new emperor Andronikos II, after which, as is believed, Theodore Skoutariotes began writing his Chronicle. He was exiled and retired to the Prodromos Monastery but was soon liberated without suffering further consequences. As it seems, Skoutariotes owned a very rich library and was in the possession of numerous manuscripts [56, S. 127, Anm. 2]. He was also identified as a writer of the two short legal comments, one regarding the retirement of a certain bishop and the other in respect to his appointment. Furthermore, Skoutariotes seems to have written two comments on the final part of Thesaurus Orthodoxae Fidei written by Choniates, as well as on the Life of the Apostle Paul [63, p. 255-256]. Theodore Skoutariotes probably died around $1305[70, \sigma .226]$.

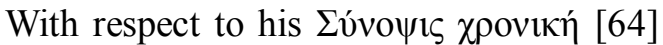
the following should be noted. Firstly, serious doubts were expressed regarding Skoutariotes' authorship. The work was found in Marcianus gr. 407 and, based on a marginal note, A. Heisenberg attributed its authorship to Theodore Skoutariotes, although the compiler of the Chronicle wished to remain anonymous as he himself stated in the introduction [64, $\sigma$. 3.313]. Doubts in Skoutariotes' authorship were expressed by A. Kazhdan who pointed out that the marginal note on the manuscript speaks rather in favor of Skoutariotes' possession and not necessarily the authorship of the text $[16$, p. 70 , 
n. 432]. Further research concluded that Skoutariotes is most probably the compiler of the aforementioned Chronicle, although certain scientific circles prefer to leave this question open $^{7}$. If we assume that Theodore Skoutariotes is the author of the work, it is important to note that he belonged to the circle close to the patriarch Arsenios Autorianos which also enabled the writer to get acquainted with emperor Theodore II. However, Skoutariotes owed his rise in career to emperor Michael Palaiologos, who appointed him to all of his ecclesiastical offices. The fact that it was precisely during the reign of Michael Palaiologos that Skoutariotes advanced in his career did not mean he had no sympathies for the Laskarid family $[16$, p. 70$]$. It should not be forgotten that many other intellectuals of that period started their careers under Michael VIII coming forward as the advocates of the Union, only to change their views with the arrival of Andronikos II to power - Gregory of Cyprus, Nikephoros Choumnos. Quite the contrary, Theodore Skoutariotes clearly expressed his preference of the Laskarids which he was able to do more freely after 1283 . Sympathies for the dethroned family and sharp criticism of the first Palaiologos were also expressed in the work of George Pachymeres who wrote his $\Sigma v \gamma \gamma \rho \alpha \varphi \iota \kappa \alpha i$

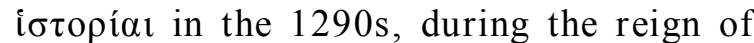
Andronikos II Palaiologos [29, S. 447-453; 66, б. 60-82; 67; 4, c. 174-175].

The Chronicle of Theodore Skoutariotes [64] (Also see [54]) is, along the History of Akropolites, one of our main sources for the study of the $13^{\text {th }}$ century Byzantine history. It is a chronicle which starts with the year of the creation of the world and describes the events until 1261, the year when the work of Akropolites suddenly stops. It is divided into two main parts - the first dealing with Biblical kings and early Byzantine period, whereas the second, more detailed, begins with the reign of Alexios I Komnenos with Choniates and Akropolites as its main sources [62, p. 774$]^{8}$. Starting from 1204/1206, Skoutariotes becomes a very close follower of Akropolites' narrative with some, as has already been mentioned, significant differences. The praise of emperor Theodore II at the very end of the description of his reign, as well as the omission of the excessive glorification of the deeds of the first Palaiologos, testify to Skoutariotes' preference of the Laskarids and his connections to the proLaskarid circle which formed a great opposition to the rule of Michael VIII. Another anonymous writer who composed a Speech dedicated to Patriarch Arsenios, a Logos that was found among the writings of Filotheos, Metropolitan of Selimvria, also belonged to the pro-Laskarid circle $[16$, p. $69 ; 35$, p. $77-78]$. Skoutariotes' work is also free from stylistic and complicated phrases that distinguish the History of megas logothetes, a fact which could serve as an argument that the Chronicle was intended for a wider audience [61, p. 34, 42-43]. The issue of the audience is therefore particularly interesting given the fact that Akropolites and Skoutariotes belonged to the two opposing circles. Thought provoking is also a fact that both Akropolites and Skoutariotes owed their rise in office and social status to the emperors they later turned their quills against. Also, it is noteworthy to say that it seems Skoutariotes had neither wish nor intention to go any further in his description of the events beyond 1261. It is as if he consciously chose not to write about controversial matters, either because he had no intention to write on his own but only to collect the material and make a compilation of the works of his predecessors, or because he had no intention of justifying his position in respect to the Church union. The reasons that instigated him to take up the task of making a synopsis Skoutariotes expressed in the introductory part of his work [64, $\sigma .3 .1-4.18]$. Finally, we must not rule out the possibility that the compiler's old age prevented him from continuing his task [64, $\sigma$. 555.25-556.7]. Whatever the case may be, the History of megas logothetes, that narrated about the restoration of the Empire represented, because of its basic theme, a convenient reading material that was, in the hands of Theodore Skoutariotes, liberated from all the disputable places or at least alleviated to the extent to which it could have been acceptable for the supporters of both the Palaiologoi and the Laskarids (On the Arsenites as a political party cf. $[65 ; 60])$.

\section{Methodology}

A comparative study of the texts of Akropolites and Skoutariotes has been carried out in order to detect all the existing differences and to make a selection of the presented material, 
since not all of the dissimilarities have the significance for this research. Apart from the analysis of the two main sources close attention has been paid to the extent to which the text of Skoutariotes' Chronicle followed other sources of the period in question in order to establish the level of its dependence on Akropolites' text since it is known that Skoutariotes employed Akropolites' sentences often verbatim. At the same time, it was also important to determine to what extent Skoutariotes used other sources of the period in question, as well as his eye-witness account. Special attention has, therefore, been paid to the expressions used in the mentioned works, for phrases can tell us a lot about the social background and impact the words had on the audience which was able or unable to fully understand their meaning [58]. Moreover, our research has also consulted other sources that gave a clearer picture of the opposing parties and their attitudes in the creation of a pro- and antiPalaiologan climate in the restored Empire (It has already been shown that Michael VIII enjoyed greater sympathies among the inhabitants of the Capital than among the people of Asia Minor, cf. [42, p. 117-118]).

\section{Results and general remarks}

The research showed that Theodore Skoutariotes had the tendency to simplify the sentence structure, sometimes even to a great extent. When relying on Niketas Choniates, Skoutariotes made even greater discrepancies in the sentence structure, as opposed to the text of Akropolites, for it is also known that Choniates wrote in highbrow language and used complicated and learned phrases [44] ${ }^{9}$. Introductory sentences to the reign of Alexios Doukas Mourtzouflos can serve as one out of many examples for this testimony. Whereas Choniates tends to express himself in a very stylistic manner, Skoutariotes simplifies his testimony to a large extent preserving, however, the point of Choniates'narrative.

\section{Nicetae Choniatae Historia} [40, S. 565.4-9]

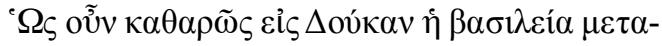

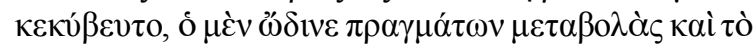

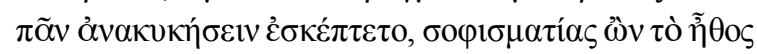

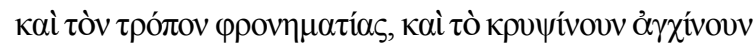

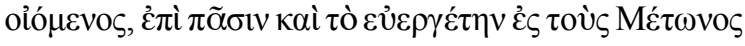

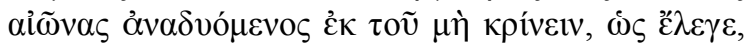

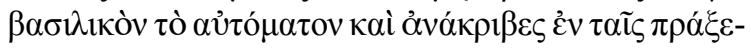

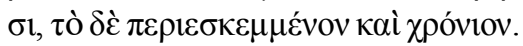

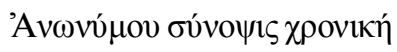
$[64, \sigma .445 .12-14]$

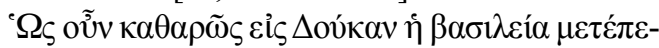

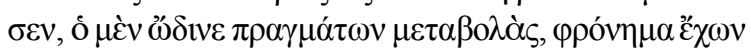

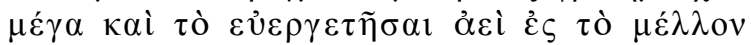

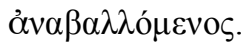

In some cases, Skoutariotes was perceived as a metaphrasis of the works of the two historians, Choniates and Akropolites, a hypothesis that cannot be entirely supported when all the discrepancies are taken into account [16, p. 67]. Also, even though the metaphraseis of the works of Choniates and Akropolites appeared very early, it has been proven that Skoutariotes used the originals while compiling his Chronicle [69, o. 131-132].

Another important aspect of the analysis was to see whether Skoutariotes relied more on the account of Choniates or Akropolites in respect to the events both of the historians narrated about. It was concluded that Skoutariotes was, in this respect, for the years 1204-1206, much more dependent on the account of Choniates ${ }^{10}$, though he omits the historian's lament on the fallen City [40, S. 647-655]. This is an interesting remark, for such an approach - greater reliance on the testimony of a historian who was closer to the events described in his work - has also been noticed in the Roman History of Nikephoros Gregoras [6, c. 61, 67-70]. The compiler of the Chronicle, however, was also to a great extent independent, which just testifies to his use of other unknown material, as well as to the fact that he was not just a mere copyist of the works of his predecessors but a skillful compiler and a careful critic of the sources that were at his disposal. Hence the narrative of Skoutariotes seems to emerge ever more as an independent and more reliable account than it has been previously given the credit for, and its compiler appears in a new light as the research on the Chronicle expands.

\subsection{Divergences concerning the reign of Theodore I Laskaris (1205-1221)}

In respect to the reign of Theodore I Laskaris the narrative of Akropolites and 
Skoutariotes do not differ to a great extent. However, the biggest discrepancy is connected to the portrayal of the emperor. Following in the footsteps of other Byzantine historiographers, Skoutariotes also dedicated the pages of his Chronicle to the descriptions and characterization of the emperors. However, unlike Akropolites who either paid little attention to characterizing the Laskarids (the case of Theodore I), or made strong efforts to present them in a negative way (John III and Theodore II), Skoutariotes presented his readers with positive images of the mentioned rulers. Therefore, it is in his Chronicle that we find more information on the Laskarid emperors than in the work of megas logothetes.

To begin with we should first focus our attention to the battle at Antioch on the Meander in 1211. As is familiar, the emperor Alexios III Angelos, who fled from Constantinople even before its fall, tried to restore the throne for himself and his successor but met with a strong opposition from the Laskarid supporters who thought Theodore I the most suitable candidate for the position of the future emperor. Alexios III, therefore, started negotiations with the Seljuk sultan, Ghiyath ad-Din Kaykhusraw I, in order to wage war against Theodore I and help him regain his throne. The decisive battle between the Byzantines and the Turks was fought at Antioch on the Meander in which Kaykhusraw lost his life and Theodore I saved his newly established Empire. This important victory of the Byzantines was described in several Byzantine sources, of which the narratives of Akropolites, Skoutariotes and Gregoras, as well as an enkomion of Choniates dedicated to Theodore I, are the most interesting for our topic. One of the decisive battles for the preservation of the Nicaean Empire was presented in the works of Akropolites and Skoutariotes in an almost identical way. Curiously enough, it is not in the works of the mentioned writers but rather in an enkomion of Choniates and in the work of a later historian, Nikephoros Gregoras, that we find more praise of the emperor for this victory. And even though all of the sources mention the duel between the sultan and the emperor, neither Akropolites nor Skoutariotes state that Theodore Laskaris decapitated the sultan ${ }^{11}$, whereas we find this information in Choniates [41, p. 174.21-27], and in a detailed description of the duel in Gregoras. Based on the almost identical accounts, it is clear that Skoutariotes used Acropolites' History as a source for his narrative about the battle, whereas Gregoras might have also consulted Choniates' enkomion. Nevertheless, it is also worth noting that Gregoras coincides in terminology with Skoutariotes and not Akropolites, when he mentions the spear on which the sultan's head was carried after the battle [64, б. 456.24-25; 39 , p. 21.3-5]. This may lead to believe either that the historian consulted the Chronicle as well, or that both Skoutariotes and Gregoras used another source which provided them with this information.

The survival of the Empire but also the destiny of Alexios III were, thus, sealed. Nevertheless, the information we find concerning the last days of his life differ in the works of our main sources - Akropolites and Skoutariotes. Namely, whereas megas logothetes only mentions that Theodore's father-in-law was taken to the monastery of Hyakinthos and soon died there, Skoutariotes mentions that the ex-emperor was blinded for his betrayal of the Romans [20, S. 17.19-23; 64, б. 457.4-12]. Interesting enough, Gregoras says that Theodore I treated his fatherin-law with respect $[39$, p. $21.18-19]$. The additional information Skoutariotes provides us with either point to his use of a source unknown to Akropolites, or to the more plausible fact that the information about blinding of Alexios III did not seem important for the megas logothetes' narrative in general. The victory on the battlefield was significant for the newly established Empire and for its preservation, though Akropolites did not give Theodore I such credit for this victory as did Choniates and Gregoras. This is also evident in the fact that both Akropolites and Skoutariotes merely mention that the peace was concluded between the Romans and the Seljouks after the battle, whereas Gregoras informs us of the peace envoys sent by the Seljouks to the emperor who was even in the position to dictate the terms of the peace treaty $[20$, S. $17.16-18 ; 64, \sigma .456 .26-$ $31 ; 43$, S. 217, Anm. 25; 39, p. 12-15].

Proof of Skoutariotes' use of other sources apart from Akropolites is an episode, found only in his Chronicle, which relates about a simple and thoughtless man who came to Nicaea in search of a good emperor. It is clear that Skoutariotes used this episode to stress Theodore I's virtues and significance and that the story, based on its nature, 
could have stemmed from oral tradition, i. e. that it was repeatedly being retold by the Byzantines and that it was something they were familiar with. After having inquired after the good emperor, the man was presented to Theodore I who asked him whether he thought him to be a good ruler. The man answered that a truly good emperor is the one who shows grace to his subjects by presenting them each with gifts. And though the emperor Theodore thought his constant fight for the protection of his people to be quite a satisfactory evidence of his care and grace, the man insisted on being given material reward, for, according to the man's opinon, the emperor's concern for his subjects was his natural debt to his people. Theodore I consented and ordered the man to be provided with various treasures, who only then acknowledged that the emperor was indeed good and most wonderful of all. [64, $\sigma .463 .3-24]$ (See Russian translation [1, c. 317-318]).

This story clearly served to prove the emperor's generosity and his openhandedness. Although George Akropolites did not relate the episode himself, there is a sentence which could testify to the fact that he too possessed the same information. In his final description of Theodore I, Akropolites mentions that the emperor was most liberal with gifts, giving much gold to whomever he wished, so that they were rich in an instant [20, S. 32.3-5; 16, p. 157].

Another information Skoutariotes thought worth mentioning as opposed to Akropolites are the names of Theodore I's sons by empress Anna, Nicholas and John, who died young [64, $\sigma .465 .30]^{12}$. Nicholas was supposed to inherit his father's throne and was even made co-emperor [45, p. 121-124; 16, p. 157-159], a fact rather important for the preservation of the dynasty and securing the continuity of the merely consolidated Empire ${ }^{13}$.

In general, the image of the first Laskarid emperor in Akropolites' work is not negative. Megas logothetes was more objective when he wrote about the founder of the dynasty than when he referred to his heirs. This is, of course, understandable when one takes into account the relationship between Michael Palaiologos and the two Laskarid emperors - John III and Theodore II. Theodore I had no connections to the founder of the Palaiologan dynasty and was an emperor who consolidated the Empire after the fall of its capital.
Therefore, Akropolites also praised him although not nearly as much as Skoutariotes did. Apart from the physical description to which we find Akropolites and Skoutariotes in agreement [20, S. 31.22-32.11; 64, б. 466.7-10], Skoutariotes adds information on the emperor's piety and his oaths in safeguarding the Orthodox faith and the traditions of the fathers from the Latins and the Persians, in this way putting an end to quarrels and damages committed on the souls of his people [64, o. 466.10-27]. Skoutariotes continues his praise stating that Theodore was a founder and father ( $\gamma \varepsilon v \alpha \dot{\alpha} \rho\rceil \varsigma)$, not only of his family but of the other emperor's that followed, who took upon himself to stand up to such a tumultuous wave, i. e. the fall of the Capital. The emperor was brave enough to face the drowning of the Roman magnificence and an utter destruction of honor of both the Empire and priesthood. Theodore I united both the Empire and priesthood, and yet he wasn't bribed, nor was he instigated by the rule over the cities, but only by the mercy of God, trying to protect his countrymen. And though he was a fugitive and homeless he became the greatest of all emperors, a second Noah, he succeeded in saving the seeds of the new life from the utter cataclysmic destruction, to raise up that which has fallen and establish himself as ruler over the Romans and Roman villages and cities, and over the high-priesthood and the senate and the army being a benefactor to all those who fled from the hands of the Latins $[64$, o. 466.28-467.26] (See Russian translation [1, c. 319-320]). Some of the orations of Niketas Choniates are also dedicated to the praise of Theodore I and might have served as a source and an inspiration for Skoutariotes [41, S. 129-147]. The praises of the emperors are to be find elsewhere in the Chronicle. These elements of panegyric clearly point to a literary education of the author [61, S. 42-43].

\subsection{John III Vatatzes (1221-1254)}

The information on the reign of John III Vatatzes in the works of George Akropolites and Theodore Skoutariotes also largely coincide, although Skoutariotes provides us with some interesting details that are not to be found in the work of megas logothetes, whereas he omits the details unfavorable to John III. Concerning the details that are to be found in the Chronicle of 
Skoutariotes we should mention the episode with the patriarchate of Tarnovo. Namely, the chronicler explains that the reason the emperor agreed to let John II Asen get the patriarchate in Tarnovo was because the Bulgarian emperor agreed to help him regain Constantinople [64, $\sigma .478 .21-29]$ ]. Also, when referring to the archbishop of Ochrid, Demetrios Chomatenos, a prominent political figure of his time, Skoutariotes provides his full name, whereas Akropolites just calls him Demetrios [64, б. 468.28-30; 20, S. 34.1]. The most important difference is the portrayal of the emperor John, for it is in the Chronicle and not in the History of George Akropolites that we find the praise of a member of the Laskarid family once again. However, it should not be forgotten that Akropolites was a

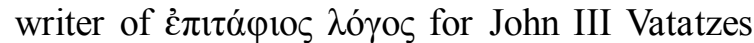
which is for the most part positive, though not entirely liberated from ironical comments [21, S. 12-29].

Firstly, the two texts differ in the depiction of the last days of the emperor's life. Akropolites merely mentions that John III came to the Eastern parts of his country and then went back to Nicaea, whereas Skoutariotes provides more exact details about his sojourn in the Empire's capital. According to the Chronicle, the emperor came there in February wanting to secure the area because he feared the Tatar incursion [20, S. 101. 19-23; 64, б. 504.16-18]. That is when an illness befell the emperor who died soon afterwards [20, S. 101.23-103.19; 64, б. 504.26-505.21] ${ }^{14}$. The greatest divergence from the text of Akropolites, however, comes with the final portrayal of the emperor. Whereas megas logothetes ironically remarks that the emperor extended a more open hand to the foreign ambassadors than to his own subjects, Skoutariotes mentiones John III's mercy

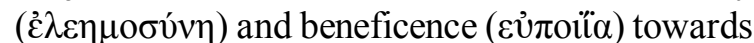
many [20, S. 103.20-23; 64, o. 505.22-31]. (See the English translation [16, p. 271]). This characteristic of the emperor was especially praised after his death and had a strong influence on the creation of his cult. It is noteworthy that at the time Skoutariotes compiled his Chronicle the cult of the emperor John the Merciful (the Almsgiver) must have been widespread, especially in Asia Minor, so it should not be ruled out that the chronicler consulted suitable texts, or at least had the cult in mind when referring to this characteristic of the emperor [35, p. 69-71]. An interesting, though ironical reference on this feature of the emperor and his cult is also made by Akropolites when he states that, in comparison to Theodore II who was so terrible to his subjects, his father was called the blessed [20, S. 105.12-14].

Another important detail is the omission of the emperor's sexual appetites in the Chronicle of Skoutariotes. There is also no mention of John III's favorite lover, Marchesina. The story of Marchesina is particularly interesting for Akropolites places it at the end of his narrative about John III. Although he does not provide many details which can be found in the writings of Nikephoros Blemmydes and the Roman History of Gregoras, one cannot escape the feeling that such a story was intentionally placed at the end of that part of Akropolites' History in order to leave a bitter taste $[20$, S. 103.23-104.10; 38, p. 35-36, 91-94; 39, p. 45.4-47.12]. (On the interpretation of the episode about Marchesina cf. [6, c. 84-87]). Skoutariotes is, on the other hand, silent on all these matters.

Skoutariotes' portrayal of John III ends with a long praise of the emperor which lacks ironical comments, characteristic for the narrative of Akropolites. Namely, Skoutariotes praises the emperor for the care for his subjects, as well as for his efforts concerning the renewal of the fortifications and the restoration of the cities no matter how small they were. John III also stowed away all sorts of weapons and there were also people in bigger cities who were craftsmen and who made various war machines. Moreover, Skoutariotes mentions that the emperor undertook various measures in order to encourage agricultural production, paying to those who fell short in money from his own treasury. The emperor also acquired cattle for the people and he founded libraries filling them with books. The reign of John III was characterized by such abundance in food and drinks and everything his subjects might wish for, so Skoutariotes asks which city, village or person was not well off in his time? A rhetorical question, indeed, though his portrayal of the Empire which flourished in Vatatzes' reign is supported by other sources [17, p. 97.21-99.24; 39, p. 42.1-20, 44.5; 25; 9]. The emperor took great care not only of his subjects, but also of people who were subjected to others. As a proof of his words, Skoutariotes names the 
monasteries on Sinai, the patriarchates of Jerusalem, Antioch and Alexandria, as well as the monasteries in Constantinople, on Mount Athos and in Thessaloniki whose benefactor John III was. Such was the emperor John III, protector, helper and a proper governor [64, б. 506.6507.20] (See Russian translation: [1, c. 321-325]). His son, Theodore II, took care of his father's funeral and buried him with great honors in his endowment, Sosandra monastery $[64, \sigma .509 .16-$ 17]. And whereas Skoutariotes has nothing but the words of praise for the late emperor, Akropolites' final statement in respect to John III is an introduction to the reign of his son: "It was the hope of all Romans, and especially of those who served in the army and those who lived in the palace, that they would gain many good things from the new emperor. And if there was anyone who had been distressed by his father or had suffered either privation of money or property, he had hopes of finding a deliverance of these misfortunes... But he (Theodore) was so bad to his subjects and he treated those under his control in such a way that they all called his father, the emperor, blessed. And if someone suffered very badly at Theodore's hands, he wished he had departed this life before his (John's) death and he longed to end his life and to be numbered by the majority" $[20$, S. $104.23-105.17 ; 16$, p. 271]. That is how megas logothetes introduces the narrative on his main negative hero, Theodore II Laksaris, whereas Skoutariotes offers a different portrait of yet another member of the Laskarid dynasty.

\subsection{Theodore II Laskaris (1254-1258)}

Probably the biggest point of departure from Akropolites' text is the part of the Chronicle which deals with Theodore II Laskaris. This is, of course, to be expected, if we take into account that Skoutariotes was personally acquainted with the patriarch Arsenios Autoreianos and emperor Theodore who were also the main opponents of Michael VIII's rise to power.

The first divergence from Akropolites' text is the story about Arsenios' coming to the patriarchal throne. According to all our sources there were several serious candidates for this position. The most prominent was certainly Nikephoros Blemmydes, one of the most learned men of his time. According to Akropolites,
Blemmydes, knowing and dreading the emperor's character, declined the offered position. However, this did not distress the emperor who was also not happy to choose Nikephoros Blemmydes. He, however, states that Theodore II pressured him to accept the position [38, p. 38-40]. Akropolites offers his readers an explanation for such an attitude of Theodore II, making an interesting remark aimed at discrediting the emperor's choice of Arsenios: "...for rulers want those who act as patriarchs to be submissive and moderate in their thinking and to succumb easily to their wishes as if they were commands. This is what happens in the case of boorish men especially, for they are not able to be confident in learning, whereas learned men appear unyielding and oppose the emperors' decrees" [20, S. 106.18-107.3; 16, p. 277-278]. Blemmydes himself also states that he was not satisfied with the emperor's character $[38$, p. 37-40]. Skoutariotes, on the other hand, mentions that Theodore II was displeased to learn that not everybody agreed on the choice of Blemmydes as patriarch, but they rather preferred someone else [64, б. 509.27-510.4]. And whereas Akropolites, Blemmydes and Gregoras only mention that there were two candidates to the patriarchal throne [16, p. 55.17-18], it appears that there were several of them. Apart from Blemmydes and Arsenios, the Logos mentions certain Kydones, hegoumenos of the Sosandra monastery [68, б. 457.237-458.254]. Eventually, as Skoutariotes explains, Arsenios Autareianos was chosen by reading of the Scriptures [64, б. 510.1-25; 68, б. 458.248-254] (See Russian translation [1, c. 325-326]).

It is clear that in respect to Arsenios, George Akropolites does not even try to hide his antipathy. Grand logothetes presented Arsenios as a man of very little education: "(He. $-B . P$. ) had little experience of letters (he had only reached the level of grammar education)" [20, S. 107.6-8; 16, p. 278]. The anonymous writer of Logos mentions that Arsenios was entrusted to patriarch Germanos II in order to receive proper education $[68, \sigma .452 .87-453.95]$. However, the information we find in other sources of the period testify to the fact that Akropolites' portrayal did not correspond to the truth, if not entirely than to a great extent. Theodore Skoutariotes provides much more details on Arsenios' background and family. We learn that the patriarch's father, 
Alexios Autareianos, was a judge in Constantinople and his mother, Eirene, stemmed from the Kamateroi family. His name was George $[68, \sigma .451 .61-62]$ and upon entering the monastery of Oxeia he took the name Gennadios. Nevertheless, he was subsequently named Arsenios, taking the first letter of his father's name. He attained education in grammar and mathematics, but, from his early childhood, Arsenios took up a yoke of solitary life and advanced in virtues. Skoutariotes also mentions that he was a hegoumenos of this monastery and that he was dispatched as an ambassador to the papal court together with the archbishops of Kyzikos and Sardis on behalf of the emperor Vatatzes. Afterwards he retired to a monastery on the Apollonias Lake where he lived in peace and quiet. When the emperor learned about the whereabouts of Arsenios, he sent for him. And so this man was taken from the yoke of the solitary life to Nicaea where he was ordained and made a deacon and a patriarch, all in one week $\left[64\right.$, б. 509. 23-512.2; 68, p. 451.61-62 ${ }^{15}$ (See Russian translation [1, c. 326-327]).

This portrayal of Arsenios and his election to the patriarchal throne are presented with much more detail in the work of Skoutariotes than in the History of George Akropolites. Skoutariotes' testimony is also supported by the Logos for Arsenios, which provides us with even more details about the early life of the patriarch. Apart from these two sources, the Roman History of Nikephoros Gregoras is also not negative in respect to Arsenios. Acknowledging that he was a man who had no experience in government affairs, and that the time required a more powerful and experienced person, someone of a stronger character who would understand the gravity of the situation, Gregoras in a way justified the patriarch, thereby mitigating Akropolites' negative portrayal. For Gregoras, Arsenios was a simple man, full of virtues but inexperienced in the political affairs. It is plausible to assume that the historian wanted to pursue the policy of a mild course in this way, presenting a more moderate image of the main characters of the period in question in order to overcome an inconvenient issue of the arrival of Michael Palaiologos to the throne [39, p. 55.16-18, 68.3-6] ${ }^{16}$.

Finishing his account on Arsenios, Skoutariotes provides an additional information that is not to be found in the work of grand logothetes. Namely, the emperor Theodore II erected a temple to St. Tryphonos, a protector of the city, and gave it the beauty and grandeur it now (i. e. the time of Skoutariotes) possesses. The emperor set up a school for grammar and rhetoric there. He hired teachers and brought pupils having provisioned money from royal treasuries. This was the first temple dressed in earthen bricks [64, б. 512.3-11] (See Russian translation [1, c. 327]). Archaeological evidence testifies to the splendor and grandeur of the church, of which very little has been preserved ${ }^{17}$. The importance of St. Tryphon for Theodore II is further described by Skoutariotes who mentiones that, on the eve of an important battle with the Bulgarians, the saint appeared to the emperor in his dream, ordering him to cross the Dardanelles. The next morning the emperor was victorious [64, б. 514.6-12]. After that Theodore II commissioned coins with the image of Saint Tryphon, his protector and the protector of his family [16, p. 284-285, n. 7].

One of the most intriguing discrepancies in the texts of the two historiographers is the account of the second Bulgarian campaign which took place in late spring/summer 1256 around Adrianople and Didymoteichon. It is intriguing because this time Skoutariotes provides us with more information about the military campaign and not about the personality and merits of an emperor. A view has been expressed that Skoutariotes has been present in the entourage of Theodore II, which would explain his firsthand knowledge of the events [16, p. 302]. At the end of the campaign Skoutariotes refers to him and the emperor saying that they have come to Kalamos [64, $\sigma .530 .18]$. This could mean that the learned chronicler took notes and included his eye-witness account in the Chronicle he compiled, or that he used another unfamiliar source to fill up his narrative with more details.

The first addition of Skoutariotes' account is a story about a hawk and a partridge chased by the hawk. Namely, as the emperor and his archons gathered in a place called Mamas, there was an omen of good news that was going to happen. The partridge, chased by the hawk, entered the room and, running past everyone, ran under the emperor's legs, whereas the hawk sat above. The emperor showed the two birds to those who were 
present and said: "Do you see this partridge? This is the Persian sultan wishing to flee for refuge to us so that we can restore him to his possessions. And this hawk, which is chasing it, represents the Tatars. I order you to let this partridge walk into your estates and cut off the hawk's head." Having said this, the emperor rushed to the western cities with a great army $[64, \sigma .522 .14-31 ; 68$, $\sigma .459 .276-285]$ (See Russian translation [1, c. 328]). The story was followed by signing a treaty with the Seljouks against the Tatars [15, p. 216].

There is no doubt that Skoutariotes used this story in order to foreshadow the defeat of the Seljouks and also to spice up his narrative. The employment of such literary technique just speaks in favor of Skoutariotes' literary engagement and not a mere compilatory work on his Chronicle. Furthermore, it is once again that we are dealing with a story which rather belongs to an oral tradition or is based on an eye-witness account. It is being told as an anecdote and could have served to point out the strength of the Empire in the time of the great campaigns. And though the army of Theodore II was more successful in the second campaign against the Bulgarians, it is to be noted that Akropolites tended to augment the perilous situation the Byzantine army found itself in and to diminish the achievements of the emperor. This is proved by further discrepancies in the texts of our two sources.

The first clash between the Byzantines and the Bulgarians ended in a disaster for the Byzantine army. Despite the order from the emperor not to engage in a battle with the enemy, the two generals, Manuel Laskaris and Constantine Margarites, thought it better to try to stand up to the enemy, but they were defeated. The accounts of Akropolites and Skoutariotes do not differ much in this regard. However, Skoutariotes provides a detail concerning the place where the generals were defeated, Barsakina [64, б. 523.17-24; 20, S. 126. 9-14]. Other discrepancies and additions to Akropolites' text concern the movement of the Scythian army, as well as the pursuit of the Scyths by George Nestongos and Cuman Kleopas. Skoutariotes adds that the Scyths plundered the region of Rhaidestos, Herakleia and Byzie [64, $\sigma .523 .27-524.1]$. Having received a detachment of the army to find the Cumans and engage them in a battle, the two men set off to find them. And whereas Akropolites mentions that the emperor failed in this enterprise, Skoutariotes offers a different perspective. He clearly states that Nestongos and Kleopas found the Cumans (Scyths), killed many of them, freed the prisoners and left the Cumans without booty [64, o. 524.5-11; 20, S. 127.21-23].

The second Bulgarian campaign ended with the peace treaty. The Bulgarians consented to handover the town of Tzepaina to the Byzantines. Theodore II stayed in the region of Regina waiting for the cession of the town, which both Akropolites and Skoutariotes inform us of. However, Skoutariotes adds a chronological detail in respect to the conclusion of the peace - it was the day in which the memory of the apostles Peter and Paul are celebrated, it was the end of June [64, $\sigma .525 .2-5]$.

One of the most distressing episodes in the narrative of Akropolites is his account of the disaccord that broke out between him and Theodore II. It was after dinner time and the sun was already rising on the horizon, when the emperor mounted on his horse and went in his usual survey of the Byzantine army. He used to call it a city on the move which guards all the Roman cities (ī

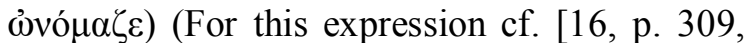
n. 4]). Skoutariotes adds that this was a clever and true remark of the wisest emperor ( $\sigma \circ \varphi \tilde{\omega} \varsigma$

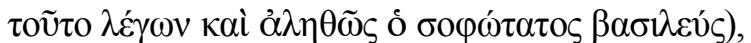
whereas Akropolites omits these epithets in his text [64, б. 525.17-19]. On the other hand, Skoutariotes omits Akropolites' incursion in the text [20, S. 128.10-18]. Following the accounts of both our writers we learn that a disturbing rumor has reached the emperor that the Russian Ouros, a father-in-law of the Bulgarian ruler responsible for the conclusion of the peace treaty between the Byzantines and the Bulgarians, swore false oaths and was deceiving the emperor. After having asked his entourage and megas logothetes not once, as stated by Skoutariotes, but several times according to Akropolites, to express their opinion on the matter and after having received the same answers, the emperor, "as if in a Bacchic frenzy" [20, S. 130.25-26; 16, p. 307], filled with anger and madness, ordered Akropolites to be whipped [20, S. 127.24-131.14]. Skoutariotes is milder in representation of Theodore II's rage; the chronicler mentions the castigation of the grand logothetes but does not make explicit mention of the whipping. 
Skoutariotes says that the emperor filled himself with great rage and wanted to take the sword out of the scabbard but he withheld from it. However, other things happened to grand logothetes that were painful, which is a clear allusion to the whipping of Akropolites. Skoutariotes continues and says that the next day Akropolites was given back his title and restored to his former honors. He was escorted to the emperor by the emperor's uncle, Manuel Laskaris and protovestiarios Mouzalon, after the painful things had been performed [64, б. 525.18-526.7]. Akropolites, understandably, provides more details in respect to the incident and makes his readers believe that a whole month passed after he had been restored to his office [20, S. 131.16-133.29]. Also, unlike Skoutariotes, Akropolites uses the opportunity to prepare the stage for the most hated characters of his work, the Mouzalones brothers. Grand logothetes relates that it was megas domestikos Andronikos Mouzalon, a man of "thin and weak little body" to take him off his mount [20, S. 130.29-131.1]. We find no such reference to Andronikos Mouzalon in Skoutariotes.

Further on, Skoutariotes and Akropolites differ in the name of the place where the encounter between the emperor Theodore and Theodora, wife of the despot Michael II Komnenos, took place. Namely, as it had already been agreed to conclude the marriage between the emperor's daughter Maria and despot Michael's son Nikephoros, Theodora came to the emperor to a place Akropolites names Langadas, where they agreed to give Servia and Dyrrachion to the emperor, so that Theodora and her son can return safely to their home [20, S. 132.30-133.18]. Skoutariotes also mentions their encounter, but he states that the meeting point was the town of Lentzas, where they celebrated the Exaltation of the Cross $\left(14^{\text {th }}\right.$ September) [64, o. 526.26-28]. Thus, the chronicler provides once again more precise information about the emperor's whereabouts and movements which might point to the fact that he was one of the bishops in Theodore II's entourage. As he later informs us, it was the patriarch Arsenios who performed marriage rites between Nikephoros and Maria [64, $\sigma .527 .4-$ 7]. Interesting enough, Akropolites does not mention that it was Arsenios who concluded the marriage between the two [20, S. 134.3-6].
Theodore Skoutariotes spices up his narrative with yet another story we do not find in the History of George Akropolites. He refers to a strange omen ( $\tau \dot{\varepsilon} \rho \alpha \varsigma, \theta \alpha v \mu \alpha ́ \sigma i o v)$ that happened at that time. After the emperor had passed through the camp, and the sun had risen, there was an imperial flag, and, as it was the custom in the military campaigns for a party of soldiers to go before the ones carrying the shield, suddenly the flag was detached from the spear because of the wind, although it was fastened well, and after it had been lifted very high up by the wind so that it could barely be observed, it suddenly fell to the ground. A lot has been talked about this incident since [64, б. 526.14-21] (See Russian translation $[1$, c. 330$])$.

An interesting episode that is not to be found in the narrative of Akropolites gets even more weight if we think of the context in which it was used and its place in the Chronicle. A fact that

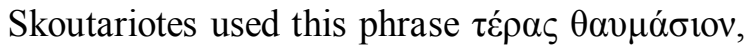
leads to the conclusion that something important and most probably negative for the Byzantines was about to happen. Two events emerge as a possible explanation for the episode, of which Skoutariotes makes no additional references. Either our chronicler referred to the war with the despot of Epirus, for the event precedes the episode in which the marriage between despot's son and the emperor's daughter is described, or he makes an allusion to the most disturbing event that followed soon afterwards - the flight of Michael Palaiologos to the Turks. As mentioned, Skoutariotes does not make any comment about the episode, thus, leaving his audience to understand and perceive it in the way it seemed more appropriate to them.

Continuing his account and returning with the emperor to the East, as Skoutariotes himself

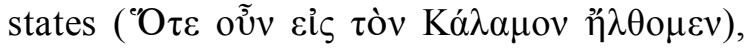
which is a clear evidence of his presence and eye-witness account $[64, \sigma .530 .17-18]$, the chronicler provides more information about the emperor's agreement with the Seljouk sultan. Sometime around the beginning of December the emperor crossed the Helespont, celebrated the birth of Christ in Syria and went straight to Lydia and, as he was marching towards Sardis, he suddenly got the message from the sultan that he was coming to meet him there. Skoutariotes provides information on the movement of both 
Theodore II and the sultan once they finally met in Sardis. After that, they went to Magnesia along with the emperor's army which was so great, as Skoutariotes remarks, so that it stretched from a place called Hlera to the straits of the river Maeander [64, б. 530.12-29]. According to the agreement, the sultan sought protection from the Tatars and it was decided that the Byzantines get Laodikeia, Chonai and two small fortresses, Sakaina and Ypsele [64, o. 531.4-7]. However, they were soon again in the hands of the Muslims, for the emperor returned them to the sultan [64, $\sigma .531 .8-9]$. And whereas we find this piece of information in the Chronicle, Akropolites says that the Romans were unable to keep the city of Laodikeia in their hands. There is no mention of the three other places Skoutariotes referred to [20, S. 144.10-15].

As was the case with the previous Laskarid emperors, Skoutariotes differs from Akropolites when it comes to the presentation of Theodore II's final hours and passing the final judgment on the emperor.

Both Akropolites and Skoutariotes mention that a terrible illness had befallen the emperor. The doctors were powerless to do anything. Not much time elapsed after the emperor had fallen ill and the illness consumed his entire body. Akropolites says that the emperor's body was reduced to a skeleton, cf. [20, S. 153.6-8]. George Pachymeres, however, relates about a long disease of the emperor and informs the readers that it lasted for a longer period [17, p. 53.1314]). The point of departure between the two narratives is Skoutariotes' mention of the patriarch Arsenios who was summoned by the emperor to ask him to whom he should reveal his deeds. The patriarch advised him to think of a person he would be willing to choose. The emperor chose the archbishop of Mytilene, a wise man, full of virtues, who confessed his soul [64, б. 533. 29-534.9]. $\mathrm{He}$ fell before his feet, imitating the whore of the Gospels, and cried the streams of tears, so that they turned into mud and he often repeated the sentence "Christ, I have forsaken thee" [64, б. 534.10-15; 20, S. 153.12-20]. The emperor repeated the same thing when the patriarch Arsenios came to give the emperor a letter of absolution [64, б. 534.16-21; 16, p. 337, n. 5]. After that, the emperor took the monastic robes leaving the earthly for the heavenly, eternal and everlasting Empire, not even ruling the full four years [64, $\sigma .534 .22-25]$ (See Russian translation [1, c. 331]). The repentant death of Theodore II and the absolution he received from the patriarch is also corroborated by Arsenios in his will [7, coll. 949]. Akropolites does not mention that the emperor became a monk, nor does he pay much attention to the phrases and expressions he used in describing his departure. His narrative is concise, also in respect to his illness, which is in accordance with the writer's dislike of this imperial figure $[20$, S. 4-25; 16, p. 336]. Both of our sources, however, agree that the emperor was buried in the monastery of Sosandra [64, б. 534.26-27; 20, S. 153.23-25].

It is worth of mentioning that a later historian, Nikephoros Gregoras, whose account is closer to Akropolites' in respect to the last days of Theodore II, is more eloquent when he narrates about the emperor's illness. Namely, the historian says that, at the age of thirty-six, the emperor was attacked by a serious illness that appeared as if to be carrying the weapons of death (ö $\pi \lambda \alpha \theta \alpha v \alpha$ d $\tau$ ov). Against the emperor's body, as Gregoras continues, the disease had set up various siege

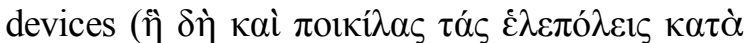
$\tau о \tilde{v} \beta \alpha \sigma \imath \lambda \iota \kappa o \tilde{v} \sigma \omega ́ \mu \alpha \tau \sigma \varsigma \alpha \dot{\alpha} \nu \tau \eta \sigma \tau \eta ́ \sigma \alpha \sigma \alpha)$. It is interesting to mention that Theodore Skoutariotes, finishing his narrative in the Chronicle, makes similar reference to his illness $(\grave{\varepsilon} \tau \imath$ $\delta \grave{\varepsilon} \kappa \alpha \grave{\imath} \tau \tilde{\omega} v$

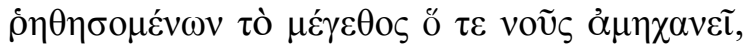

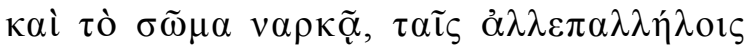

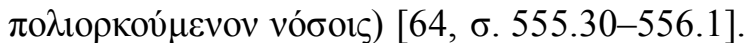
And even though Gregoras does not mention the absolution given by the archbishop of Mitylene and the patriarch, he states that the emperor took the monastic robe and, after having cried the streams of tears, departed from the world [39, p. $61.18-25,62.2]$. (About tears cf. [28, p. 130; 27]).

Apart from different portrayal of the emperor's final hours, it is Skoutariotes that devoted two pages to the praise of the emperor, as well as to the exaltation of his learning and

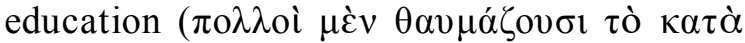

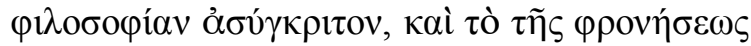
$\left.\omega \varsigma \dot{\alpha} \lambda \eta \theta \tilde{\omega} \varsigma \dot{\alpha} \pi \alpha \rho \alpha \dot{\mu} \mu \lambda \lambda \lambda^{\circ} v\right)$. Also, the emperor was admired for his considerable strategic qualities and recklessness with which he scared off the enemies, not just the Persians who approached him in a servile manner, but also the Arabs and the Egyptians, whose monarch he won 
over by sending glorious gifts. There existed the people who worshiped the love of honor, munificence and the wealth-creativity of his right hand, but there were also others who gradually destroyed and were stricken by his many and great God given privileges. Theodore II also augmented to a great extent, everything his father and emperor cared for and maintained. Skoutariotes adds a personal note when he states that he is praising him because of the proceeding of the story and because of his great knowledge and wisdom, and as he loved those who are versed in stories and loved to reflect with such friendliness deeply inside, he (Skoutariotes) has no one so eager in these matters he could measure him up to [64, $\sigma .535 .5-25]$. Of particular importance is that the emperor gathered books, not only those of the great Ptolemy, but of many other arts and sciences and he filled all the Roman cities with them, a fact which was especially important given into account the disaster that struck the Empress of the Cities. He built libraries and theaters, brought learned men to the cities of the Empire, so once again the debates about logical questions and conclusions could be heard in the markets. But, alas, a common misfortune happened and this emperor died, not having ruled the entire four years. A natural debt had to be paid and after the departure of his earthly body it fell to lot to those who tasted some of his grace, and of course to


the things concerning him $[64, \sigma .535 .26-12]$ (See Russian translation [1, c. 332-333]). It seems as if this final remark was directed to the people who transgressed the oaths given to Theodore II on his deathbed and was related to the events that followed.

The portrait of the Laskarid emperors in the work of Theodore Skoutariotes is, as is shown, positive and favorable to the members of this dynasty. Skoutariotes' positive feature as a writer/compiler is that he tended not to conceal even some less complimentary events (the castigation of Akropolites) and characteristics (Theodore II's moody temper) of the monarchs, though he did try to mitigate them. Some of the totally unfavorable features Skoutariotes did leave out (John III's apetite for women). However, it is noteworthy to say that his additions to or omissions from the text of Akropolites were easily discovered, for the author does not seem to have tried to disguise them. In respect with the account on Michael VIII and his reign, tendency to mask certain phrases and to employ word games has been spotted. On more than one occasion, Skoutariotes skillfully used word play to write completely opposing statements to Akropolites'text, which only makes the question of the audience, as well as Skoutariotes' writing skills more interesting.

\subsection{Michael VIII Palaiologos (1259-1282)}

The heir to the Nicaean throne after the death of Theodore II was his minor son, John IV Laskaris. The emperor left his closest associate and friend, protovestiarios George Mouzalon, as epitropos. All the historians who narrate about these events agree on this point. What draws particular attention, however, is the mention of the will written by Theodore II on his deathbed. Both Akropolites and Skoutariotes mention that Theodore II had drawn up a testament for his son and heir, but that the document was in reality more beneficial to George Mouzalon whom the emperor had made the master of all Roman

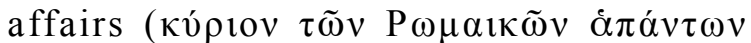
$\pi \rho \alpha \gamma \mu \alpha ́ \tau \omega v)[20$, S. $154.13-15 ; 16$, p. 340, n. 2 ; 64, б. 536.13-20]. Pachymeres mentions a written order ( $\dot{\varepsilon} \pi \imath \tau \tau \mathrm{O} \lambda \grave{\alpha} \varsigma \pi \lambda \eta \rho \tilde{\omega} v \beta \alpha \sigma \iota \lambda \varepsilon \dot{\varepsilon} \omega \varsigma$ ) entrusted to Mouzalon as regent [17, p. 71.9-13]. Gregoras also informs us of a written will, indicating that Mouzalon was entrusted with the care of the Empire and he mentions the multiple oaths of allegiance given to the emperor and his protovestiarios, but the historian does not stress that the testament was made in favor of Mouzalon [39, p. 63.10-13]. George Akropolites is extremely negative towards the Mouzalones brothers. In his animosity towards them he goes so far as to say that they were not even worth the three obols [20, S. 124.10-12] ${ }^{18}$. On the other hand, Skoutariotes was not at all negative towards the brothers. What is more, he provides us with information regarding the military duties of George Mouzalon which Akropolites prefers to leave out $[64, \sigma .514 .3-4,14-15]$. Other historians, George Pachymeres and Nikephoros Gregoras are also not negative in their portrayal of George Mouzalon. Based on their testimonies, he was a man of great inteligence [17, p. 64-79; 39 , p. 62.3-19]. 
The brutality of the murder of the Mouzalones is evident in all of the sources. George Akropolites accentuates the wrath the aristocracy felt towards the protovestiarios, but he, as is expected, justifies their behavior by the negativity with which he portrayes the Mouzalones. The bodies of the Mouzalones brothers were cut into pieces, but it all happened because of the unstoppable rage the members of the aristocratic families felt for them. It was not the aristocracy to blame, it was the emperor, for he had given the rule over the Roman affairs "...to loathsome little man, worthless specimens of humanity who had been raised on the songs of the theatre and took pleasure in the flute and strings and practiced, to use the Homeric phrase, 'false of tongue, nimble of foot, peerless of beating the floor in dance', while he neglected noble men and expert commanders who had given good and pleasing service to the emperor his father" $[20$, S. 154.24-156.18]. (The English translation see [16, p. 339-340]). Theodore Skoutariotes also mentions the brutality with which the brothers were killed, the chopping of their bodies, but he omits the part about the justification of the rage of the aristocratic families, although he does admit that there were families which were maltreated by the emperor (oi

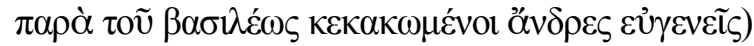
[64, б. 536.23]. Skoutariotes, however, provides additional information as to how it came to the Mouzalones' murder. Namely, the writer relates that the body of the emperor was displayed in the monastery of Sosandra and that the protovestiarios was performing funeral rites. When Mouzalon was about to leave the monastery several members of the aristocratic circle, fearing that he might gain the people to his side, approached the dying emperor and started once again swearing oaths they had previously given. They persuaded the protovestiarios to stay in the temple together with his brothers and the slaughter ensued [64, $\sigma .537 .8-27]^{19}$ (See Russian translation [1, c. 333$])$.

Once George Mouzalon was murdered the Roman people, those in office together with the military and the holy order started discussing the matter of the election of the new epitropos. And whereas Akropolites states that the patriarch was also present there, Skoutariotes, as well as Arsenios in his $\delta 1 \alpha \theta \eta \dot{\kappa} \kappa$, state that the patriarch came from Nicaea to take part in these matters [20, S. 156.19-157.2; 64, б. 537.28-31; 7, coll. 949C]. As is familiar, a man who was thought the most appropriate for the position was Michael Palaiologos.

In the historical work of George Akropolites the character of Michael Palaiologos is gradually formed. The historian mentions the nobility of his birth by mentioning his father Andronikos, megas domestikos, with all the epithets deserving of such a man $[20$, S. 3.27-74.12, 83.20-22, 84.4-6; 16, p. 242]. Another source, most favorable to Andronikos Palaiologos corroborates Akropolites' glorification of domestikos' deeds - Jacob, the archbishop of Ochrid. He eulogized in his Monody and the elegiac verses the father of the founder of the Palailogan dynasty, the great domestikos Andronikos and his offspring [37, p. 65-80]. Also, in his praise of the emperor John III Vatatzes, Archbishop Jacob left valuable information on the expedition to the island of Rhodes which was led by Andronikos Palaiologos [37, p. 88.23-89.11]. There is, however, not much information on the personality of Jacob in the sources. It can be assumed that he occupied the position of the archbishop until 1246, when he fled to Thessaloniki to Andronikos Palaiologos, probably because of the resistance of the local population. As bishop of Bulgaria Jacob signed various documents until 1253 after which he went to Mount Athos where he became the abbot of the Lavra Monastery. He was in close relations with the Palaiologoi and, thus, probably with the latter emperor Michael. Jacob probably died around 1298. In his Apology patriarch John Bekkos mentioned him as deceased and it is believed that, since Bekkos died in 1298, Jacob passed away sometime earlier [31, coll. 977] ${ }^{20}$. However, unlike Akropolites who speaks favorably of Andronikos' administration in Macedonia, Theodore Skoutariotes gives a somewhat different picture. And whereas Akropolites states that Andronikos governed well, Skoutariotes states quite the opposite:

$$
\begin{aligned}
& \text { Georgii Acropolitae Opera } \\
& \text { [20, S. 84.13] }
\end{aligned}
$$

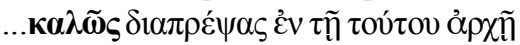

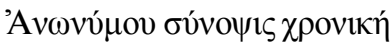

$$
\begin{aligned}
& {[64, \sigma .498 .12]}
\end{aligned}
$$

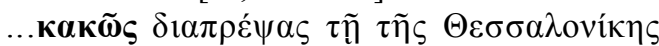

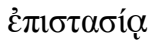

There is, however, not enough evidence to corroborate either of the two statements [16, 
p. 244, n. 6]. Apart from that, on several occasions Skoutariotes omitted the excessive praise of Michael VIII's father we find in the text of Akropolites. When megas logothetes expressed his opinion on Andronikos as: “... a most intelligent and gentle man, well-acquainted with arming for battle and governing people in times of war and peace" [20, S. 83.18-22; 16, p. 242], a statement which clearly served to outline the abilities and capacities of his son and later emperor, Skoutariotes leaves these epithets out of his narrative, but admits, as does Akropolites, that Andronikos was: "marvelled at by all and celebrated for so speedy and great a victory, not only by his own people but also by foreigners" [20, S. 83.22-25; 16, p. 242; 64, б. 497.20-23].

Other important issues in respect to Michael Palaiologos are the charges against "the lèsemajesté" to which he was subjected on two or three occasions. It is only in the work of Pachymeres that we find the information on the third charge against Michael [4, c. 146]. In respect to this matter, texts of Akropolites and Skoutariotes do not differ greatly. There are, however, slight but significant discrepancies. Akropolites, who was also an eye-witness of the events, is very detailed in his long account on how it came to the accusations against Michael Palaiologos, finishing his account with the famous ordeal by red hot iron [20, S. 92.25-100.14]. Skoutariotes is, on the other hand, a lot briefer and does not mention the ordeal at all. The omission of the story about the ordeal is even more important if one takes into account that it is precisely on the origin of the ordeal that Akropolites builds his account about Michael Palaiologos as a protector of Roman custom and Roman ways [16, p. 266-267, n. 26; 4, c. 145]. What Skoutariotes does mention, however, is that Michael was held in suspicion even after he had been released, an interesting remark if we take into account that there was another accusation against his persona [64, $\sigma .503 .4-504.13]$. (See also [16, p. 259-268; 4, c. 145]). In respect to the second process Akropolites and Skoutariotes are more or less in agreement. However, Skoutariotes omits Akropolites' incursions in the text, but both of our sources agree that Theodore II gave an oath to Michael guaranteeing him safety and reinstated him to his previous position [20, S. 134.7-138.20, 144.20-23; 64, б. 527.8-528.27,
531.15-17; 16, p. 312-321, 326, 327-328, n. 9; 4, c. 146].

It is also worth mentioning that Skoutariotes omits to narrate about the battle at Vodena in 1257, which Akropolites uses to point out the military skills of Michael Palaiologos: "...he was strong in arm, brave in disposition, and tried in battle; he had been trained in many previous wars" [20, S. 147. 18-20]. (The English translation see [16, p. 330-331]). Interesting enough, Akropolites is the only source which refers to this event. Michael's warrior skills are also augmented in Akropolites' account of the campaign that resulted in the capture of Prilep, where Akropolites was in command, by despot Michael II Komenos. Probably wanting to absolve Palaiologos from the failure of the Byzantine army, Akropolites notes that the emperor Theodore: “...gave him an army from Macedonia which was very small in size and worthless in quality" [20, S. 145.4-5]. (The English translation see [16, p. 328]). Skoutariotes does not make such a comment on the emperor's army [64, б. 531.17-19]. Also, when describing the campaign of 1259, Akropolites refers to Michael Palaiologos and his dependence on God, thus stressing his piety, whereas Skoutariotes leaves that comment out of his narrative [20, S. $150.22-23$; 16, p. 359 , n. 7; 64, б. 543.2-4]. Significant discrepancy is also to be noted in the description of the siege of Galata. Akropolites presents this campaign as an insignificant and minor one, whereas Skoutariotes, Pachymeres and Gregoras speak of this endeavour as a serious one. Skoutariotes is chronologically more precise than Akropolites, for he notes that Michael's attempts in taking Galata lasted from January to April [20, S. 173.19-175.19; 64, б. 546.24547.24]. (On other sources cf. [16, p. 368]).

The greatest divergence between the texts of the two sources is related to the return of Arsenios to the patriarchal throne. Namely, after having crowned Michael VIII as emperor for the first time and before the legitimate heir, John IV, Arsenios resigned from his position and the new patriarch was elected. However, as the patriarch Nikephoros died soon after he had been elected, the question of the election arose again. Both of the sources remind us that it was Theodore II who first elected Arsenios as Byzantine patriarch, but Akropolites and Skoutariotes totally differ in the way they write about Arsenios. Akropolites 
states, once again, that he was "...a dull man both in speech and in deed. He had no reason adorning him, neither that which comes from an education nor that produced by nature but, in addition, he had an unpleasant disposition and was obdurate in manner, quick in enmity, slow in friendship, and bearing ill will like a shadow following the body" [20, S. 177.7-178.5]. (The English translation see $[16$, p. 370]). As opposed to that Skoutariotes offered a completely distinct image of Arsenios, stating that he was a man of a good natural disposition that stemmed from his very nature. He also had some knowledge and he was not ignorant of philosophy, but he wounded his soul by an arrow for the love of God when he was very young, for he preferred the solitary life. Especially interesting are the words and phrases both of our writers used, for it seems that Skoutariotes played with the expressions he found in Akropolites to make his portrait of Arsenios totally opposite to the one we find in the work of megas logothetes:

\section{Georgii Acropolitae Opera}

[20, S. 177.7-178.5]

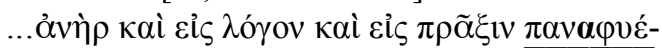

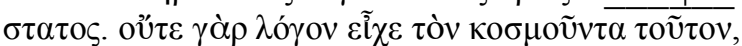

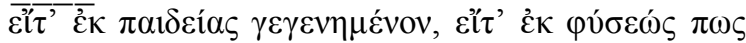

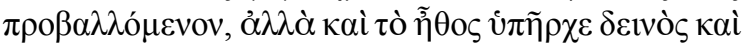

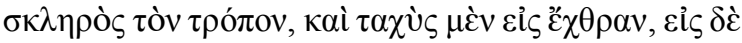

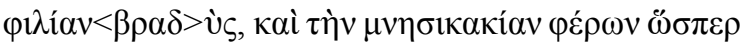

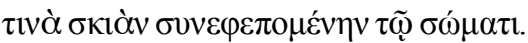

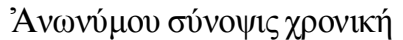
$[64, \sigma .548 .19-26]$

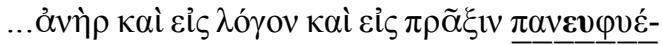

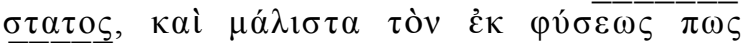

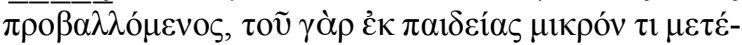

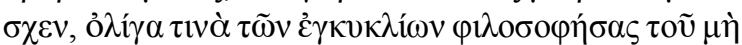

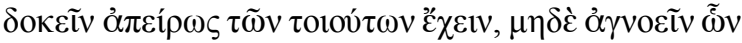

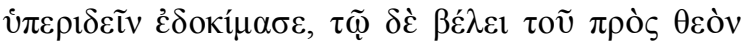

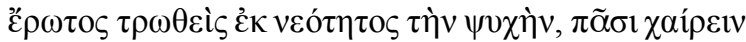

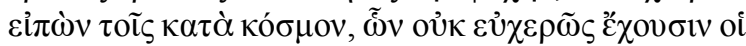

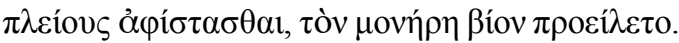

Akropolites goes on to say that in the beginning of Michael's reign, Arsenios did everything that the emperor asked and that he suddenly changed for the worst, having as accomplices Andronikos, the archbishop of Sardis and Manuel, called Opsaras, of Thessaloniki [20, S. 178.8-179.1]. Skoutariotes, on the other hand, states that Arsenios fulfilled the imperial coronation of Michael Palaiologos, but when he saw that the emperor was not giving way to his counsel he came to differences with him, and having become dissaffected with him, he was driven away from the throne. In the same way were affected Manuel of Thessaloniki and Andronikos of Sardis who were banished from the church $[64, \sigma .548 .30$ 549.1]. Akropolites was also more positive towards the newly elected patriarch Nikephoros, for he portrays him as "a most chaste and moderate man in speech and manner, pleasant to all who knew him" [20, S. 180.2-4]. (The English translation see [16, p. 370]). Skoutariotes leaves out such a characterization of Nikephoros. An interesting observation is also the way in which Akropolites portrays the second coming of Arsenios to the throne. Megas logothetes exclaims that he does not know how sebastokrator Tornikes succeeded in pressing the emperor to return Arsenios to the throne, describing to him some miracles of the patriarch [20, S. 180.5-11]. Skoutariotes also mentions Tornikes as the one who compelled the emperor return Arsenios [64, б. 549.18-22], but, whereas Akropolites finishes his account with the following statement: "the emperor's goodness and readiness to do good made him agree to the advice of the sebastokrator, and Arsenios was again elevated to the patriarchal throne, having stated in writing that he would think and act rightly with regard to the emperor", Skoutariotes completely omits this remark of the megas logothetes [20, S. 180.11-15]. (Also see [16, p. 371, 375, n. 17 ; 1, c. 334-335]).

However, the chronicler chooses to write about Arsenios again, this time as an eye-witness, providing his opinion on the matter ${ }^{21}$. He says that the ones accused of having dissaffection in regard to the emperor have been falsy convicted. They have both (Arsenios and Michael) suffered from one another. However, Skoutariotes accentuates that he was a witness in all the matters, for he took part in practice and counsel day and night and lived together with the patriarch under the same roof. Arsenios, being a true archbishop, teacher and shepherd wanted his flock to be pious and demanded the same in return. Nevertheless, his flock did not step forward to virtue, but it rather dragged God's wrath upon itself because of the transgression of frequent and horrible oaths ( $\delta i \grave{\alpha} \tau \tilde{\eta} \varsigma \pi \alpha \rho \alpha \beta \alpha ́ \sigma \varepsilon \omega \varsigma \tau \tilde{\omega} v \sigma v \chi v \tilde{\omega} v$ $\kappa \alpha i ̀ ~ \varphi \rho ı \tau \tau \tilde{\omega} \nu$ ó $\rho \kappa \omega \mu о \sigma \imath \tilde{\omega} v)$, and since the repentance also wasn't like it was supposed to be, he 
made repentance for the salvation and demanded back the same. He strived for the good and reproached the sinful for the emendation [64, $\sigma .549 .23-550.16]$ (See Russian translation [1, c. 335]).

It is clear from the testimony of Skoutariotes that he referred to the usurpation of the throne that was to be committed by Michael Palaiologos. The writer's intrusion in the text at this point clearly served to make his testimony more reliable and to stress the correctness of the patriarch's actions. Worth mentioning are also the expressions Skoutariotes employed to denote the oaths given by both parties - Michael Palaiologos and John Laskaris - that were transgressed several times. Patriarch Arsenios also informs us of this in his Will, using similar expressions (о̋

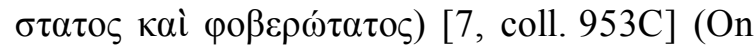
Arsenios' account of the transgression of oaths cf. [7, coll. 949-953]). So it is more than plausible that Skoutariotes consulted the patriarch's testament ${ }^{22}$

As has already been mentioned, Akropolites' text ends abruptly with his intention to insert the speeches he had composed on the occasion of Michael's triumphal entry into Constantinople. Skoutariotes, on the other hand ends his account mentioning the great logothetes' speeches, stating that the time has come to put an end to his account because of his old age and because of the illness which is taking over him [64, б. 555.17-556.14]. In this fashion end both of our narratives on the reigns of the Laskarids and Michael VIII Palaiologos.

\section{Conclusion}

The information Skoutariotes provides in his Chronicle in respect to the Laskarid dynasty and Michael VIII Palaiologos is valuable. Most of it can be confirmed in other sources, both contemporary and later. The omissions from his text were mostly in the service of offering his readers a more moderate portrayal of a very biased account of his main source, George Akropolites, whereas the additions tend to show the writer's engagement in writing his own narrative. Even though his only intention was to write a synopsis of the most important events, it is clear when analyzing different levels of style employed in the Chronicle, the employment of elements of rhetoric (eulogizing the emperors, making biographical portraits which is clear from the narrative structure, using word play) and the fact that the author made use of different source material to which we should add his own eye-witness account, that he had more ambition than just making his work a mere compilation [61, p. 34-37]. It is more probable that such a compilation was intended for the earlier part of his Chronicle, but in respect to the events starting from the fall of Constantinople a hypothesis can be expressed that something else was intended. Lacking the stylistic beauty of a sentence and complexity of phrases so preferred by the Byzantine writers, for the Chronicle was supposed to address the audience which was neither well-educated nor familiar with the $\lambda$ ó $\gamma \circ$ $[64, \sigma .4 .6-7]$, it can be concluded that Theodore Skoutariotes tended to offer to his readers, a wider audience than the one which was able to understand Akropolites, his own view of the main protagonists of the $13^{\text {th }}$-century Byzantium. He provided his contemporaries, but also the following generations, with an alternative to the narrative of Akropolites, and he provided his fellow historians with a possibility to verify the account of the learned grand logothetes. It was not a curious thing for the same writer to produce two versions of his own text (such were the versions of Niketas Choniates' History who made one final revision of his historical work in 1215/17 [49]), and it was certainly not a peculiar thing to have two versions of the same events by two different writers. Even though we cannot be certain whether the later historians, George Pachymeres (also a church official) and Nikephoros Gregoras, consulted his work, it should be noted that both of these two writers gave a very positive portrayal of the Laskarid emperors. On the other hand, Pachymeres gave an extremely negative account on the reign of Michael VIII, whereas both Skoutariotes as well as Gregoras, mitigated both extremely positive and negative portrayal of the first Palaiologan emperor. Therefore, Skoutariotes might have been an adequate reading material for the later writers, because, with the help of his work they were in ability to validate the objectivity of Akropolites' testimony and to get a clearer picture of the events of their time. It should not be forgotten that a $14^{\text {th }}$-century writer, Ephraem of Ainos, composed a work for which it was concluded relied mostly on the account of Akropolites (For the sources of Ephraem cf. [33]). Bearing in mind the similarities in the expressions 
used in the works of Akropolites and Skoutariotes and the fact that Ephraem praised the Laskarid emperors in his work [12, p. 279-280, 327], it is not at all to be excluded that the author was familiar with the text of Skoutariotes. As a result of all that has been said, the Chronicle of Theodore Skoutariotes should be consulted to a much greater extent than it has previously been the case, bearing in mind that one may find interesting and significant information about the restoration of the Empire after its fall in 1204.

\section{NOTES}

${ }^{1}$ This article has been written as a result of the research conducted within the project "Tradition, Innovation and Identity" (No 177032) of the Ministry of Education, Science and Technological Development of the Republic of Serbia. Scientific editing of the article is carried out by Yury Vin.

${ }^{2}$ A well-known episode from Akropolites describes how Theodore II Laskaris, in one of his furious outbursts, ordered to have the megas logothetes whipped [20, S. 130.29-131.22; 16, p. 307].

${ }^{3}$ The degree of kinship between Eudokia and Michael Palaiologos has so far not been established; cf. [16, p. 18].

${ }^{4}$ Detailed information about the Council can be found in the work of George Pachymeres [19, p. 35-37].

${ }^{5}$ Significant account about the history and dogmatic issues that followed the negotiations on the Union was left by the father of Theodore Metochites, George Metochites [22; 23].

${ }^{6}$ The same document was signed by historian George Pachymeres [24, p. 30].

${ }^{7}$ On the problems related to Skoutariotes' authorship cf. [55; 62].

${ }^{8}$ On the time structure of the text cf. [61, p. 37-38].

${ }^{9}$ On the language of the learned elite cf. [47; 48; 59, p. 117]. On Skoutariotes' employment of Choniates' text cf. also [50, p. 125].

${ }^{10}$ It is interesting to note that Akropolites gives the wrong year for the fall of Constantinople to the Latins [20, S. 7.23-8.1], whereas Choniates and Skoutariotes both note the right date [40, S. 569.7-10; 64, б. 446.27-31].

${ }^{11}$ Akropolites provides this information in another place of his work [20, S. 27.8; 64, $\sigma .456 .20-22]$.

${ }^{12}$ Akropolites also refers to the two early deceased sons of Theodore I without mentioning their names [20, S. 31.13-17].

${ }^{13}$ On the co emperors in Nicaean period cf. [2].

${ }^{14}$ On further reference about the emperor's illness cf. [17, p. 99.27-101.3; 39, p. 49.23-24].
${ }^{15}$ The Logos for Arsenios mentions that the name of Arsenios' father was Theodore, cf. [68, $\sigma .451 .54$ 55]. Also, this source mentions the patriarchs's mother, Eirene $[68, \sigma .451 .55-56]$. At the same time, the anonymous writer adds that Arsenios was a blood relation of the Choumnos family, although no further conclusions can be made on account of this information, cf. [68, $\sigma .452 .85-87]$. Certain doubts have been expressed that the authors of Logos might have been Maximos Planoudes or Nikephoros Choumnos, cf. [68, $\sigma .436-442]$.

${ }^{16}$ On Gregoras' views on the main protagonists of the $13^{\text {th }}$-century Byzantine politics cf. [6, c. 87-96].

${ }^{17}$ On more information on the church cf. [13, p. $104-108 ; 14$, p. 132].

${ }^{18}$ On the proverb used on this occasion by Akropolites cf. [16, p. 300, n. 8]. The same proverb will be used by the historian in the story about the murder of the Mouzalones, cf. [20, S. 156.9-14].

${ }^{19}$ On the accounts of Pachymeres and Gregoras in respect to the murder cf. [6, c. 104-105].

${ }^{20}$ Also see $[37$, p. $101-106 ; 11]$. On the date of the death of John Bekkos cf. [34].

${ }^{21}$ On the writer's intrusions in the text cf. [26].

${ }^{22}$ George Pachymeres also relates in detail about the transgression of the oaths $[17$, p. 134-137. 16, 1-2, 257. 10-15; 18, p. 181.10-12, 225.7-24].

\section{REFERENCES}

1. Litavrin G.G., ed. Georgiy Akropolit. Istoriya [George Akropolites. History]. Saint Petersburg, Aleteya Publ., 2005. 415 p.

2. Zhavoronkov P.I. Izbranie i koronatsiya nikeyskikh imperatorov [The Election and Coronation of the Nicaean Emperors]. Vizantiyskiy vremenik [Byzantina Xronika], 1988, vol. 49, pp. 55-59.

3. Zavrazhin V.N. K voprosu o tolkovanii odnogo fragmenta iz prilozheniy Feodora Skutariota [On the Question of Interpretation of One Fragment from the Work of Theodore Scoutariotes]. Vizantiyskiy vremenik [Byzantina Xronika], 1980, vol. 41, pp. 252-255.

4. Nikolić M., Pavlović B. Slika Mihaila VIII u delima istoričara epohe Paleologa [The Image of Michael VIII in the Historical Works of the Palaiologan Period]. Zbornik radova Vizantološkog instituta [Collection of Works of Byzantine Institut], 2017, vol. 54, c. 143-181. (in Serbian).

5. Nikolov A. Retsenziya: Georgiy Akropolit. Istoriya (V perevode P.I. Zhavoronkova) i George Akropolites. The History (transl. by R. Macrides) [Review: George Akropolites. History (transl. by P.I. Zhavoronkov) and George Akropolites. The History (transl. by R. Macrides)]. Vestnik Pravoslavnogo 
Svyato-Tikhonovskogo gumanitarnogo universiteta. Seriya I: Bogoslovie. Filosofiya. Religiovedenie [St. Tikhon's University Review. Theology. Philosophy. Religious Studies.], 2009, vol. 1 (25), pp. 108-113.

6. Pavlović B. "Romejska istorija" Nićifora Grigore : istorijska analiza dela: dis. ... st. d. n. ["The Roman History" of Nikephoros Gregoras: Historical Analysis of His Work]. Beograd, 2018. 535 c. (in Serbian).

7. Arsenius, patr. Testamentum. Migne J.-P., ed. Niketae Choniatae Opera omnia. Paris, In via dicta Thibaut, 1865, coll. 948-957. (Patrologiae Cursus Completus, Series Graeca, vol. 140).

8. Thomas J., Constantinides Hero A., Constable G., eds. Byzantine Monastic Foundation Documents: A Complete Translation of the Surviving Founders' Typika and Testaments. Vol. 3. Washington D.C., Dumbarton Oaks Research Library and Collection, 2000. XIII, 435 [859-1294] p.

9. Charanis P. The Aristocracy of Byzantium in the Thirteenth Century. Colleman-Norton P.R., ed. Studies in Roman Economic and Social History in Honor of A.C. Johnson. Princeton, Princeton University Press, 1951, pp. 336-355.

10. Croke B. Uncovering Byzantium's Historiographical Audience. Macrides R., ed. History as Literature in Byzantium: Papers from the Fortieth Spring Symposium of Byzantine Studies, University of Birmingham, April 2007. Aldershot, Ashgate Publishing, 2010, pp. 25-53.

11. Dujčev I. Un nouveau temoignage de Jacques de Bulgarie. Byzantinoslavica, 1960, vol. 21, pp. 54-61.

12. Lampsides O., ed. Ephraem Aenii Historia Chronica. Athens, Academia Atheniensis, 1990. LX, $456 \mathrm{p}$.

13. Foss C., Tulchin J. Nicaea: A Byzantine Capital and Its Praises. With the Speeches of Theodore Laskaris; In Praise of the Great City of Nicaea; and Theodore Methochites, Nicene Oration. Brookline, Massachussets, Hellenic College Press, 1996. IX, $256 \mathrm{p}$.

14. Foss C. Pilgrimage in Medieval Asia Minor. Dumbarton Oaks Papers, 2002, vol. 56, pp. 129-151.

15. Gardner A. The Lascarids of Nicaea. The Story of an Empire in Exile. Amsterdam, A. Hakkert, 1964. XIII, $321 \mathrm{p}$.

16. Macrides R., ed. George Akropolites. The History. Oxford, Oxford University Press, 2007. XXI, $464 \mathrm{p}$.

17. Failler A., éd. Georges Pachymérès. Relations historiques. Vol. 1. Paris, La soc. d'éd. "Les belles lettres", 1984.326 p.

18. Failler A., éd. Georges Pachymérès. Relations historiques. Vol. 2. Paris, La soc. d'éd. "Les belles lettres", 1984. I, 339 [326-667] p.
19. Failler A., éd. Georges Pachymérès. Relations historiques. Vol. 3. Paris, La soc. d'éd. "Les belles lettres", 1999. XXIV, 305 p.

20. Heisenberg A., Wirth P., eds. Georgii Acropolitae Opera. Bd. 1. Stuttgart, B.G. Teubner, 1978. XXVIII, $366 \mathrm{p}$.

21. Heisenberg A., Wirth P., eds. Georgii Acropolitae Opera. Bd. 2. Stuttgart, B.G. Teubner, 1978. XXVI, 121, XXIX-XLII p.

22. Georgii Metochitae Historia Dogmatica. Lib. 1-2. Cardinal Mai A., Cozza-Luzi J., eds. Patrum Nova Bibliotheca. Vol. 8, Pt. 2. Romae, Apud I. Spithoever, 1871. I. 228 p.

23. Georgii Metochitae Historia Dogmatica. Lib. 3. Cardinal Mai A., Cozza-Luzi J., eds. Patrum Nova Bibliotheca. Vol. 10, Pt. 1. Romae, Bibliotheca Vaticana, 1905, pp. 319-370.

24. Gill J. The Church Union of the Council of Lyons (1274) Portrayed in Greek Documents. Orientalia Christiana Periodica, 1974, vol. 40, pp. 5-45.

25. Glykatzi-Ahrweiler H. La politique agraire des empereurs de Nicée. Byzantion, 1958, vol. 28, no. 1, pp. 51-66.

26. Hinterberger M. Autobiographische Traditionen in Byzanz. Wien, Verl. d. Österreich. Akad. d. Wissensch., 1999. 415 S. (in German).

27. Hinterberger M. Tränen in der byzantinsichen Literatur. Ein Beitrag zur Geschichte der Emotionen. Jahrbuch der Österreichischen Byzantinistik, 2006, Bd. 56, S. 27-51.(in German).

28. Hinterberger M. Emotions in Byzantium. James L., ed. A Companion to Byzantium. Chicester, U.K., WileyBlackwell Publ. Ltd, 2010, pp. 123-134.

29. Hunger H. Die hochsprachliche profane Literatur der Byzantiner. Bd. I. München, C.H. Beck'sche Verl., 1978.542 S. (in German).

30. GrégoireH., ed. Imperatoris Michaelis Palaeologi de vita sua: Opusculum necnon Regulae quam ipse monasterio S. Demetrii praescripsit fragmentum. Byzantion, 1959-1960, vol. 29/30, pp. 447-475.

31. Ioannes Veccus, Cp. patr. Oratio Secunda Apologetica. Migne J.-P., ed. Ioannis Vecci, Cpl. patriarchae, Opera omnia. Paris, In via dicta Thibaud, 1865, coll. 969-1010. (Patrologiae Cursus Completus, Series Graeca, vol. 141).

32. Kinloch M. Rethinking Thirteenth Century Byzantine Historiography: A Postmodern, Narrativist and Narratological Approach: Ph.D. Thesis. Oxford, 2018.339 p.

33. Lampsides O. Beiträge zum byzantinischen Chronisten Ephraem und zu seiner Chronik. Athens, I. Kollaros, 1972. 180 p.

34. Laurent V. La date de la mort de Jean Beccos. Echos d'Orient, 1926, vol. 25, pp. 316-319.

35. Macrides R. Saints and Sainthood in the Early Palaiologan Period. Hackel S., ed. The 
Byzantine Saint: University of Birmingham. Fourteenth Spring Symposium of Byzantine Studies. London, Fellowship of St. Alban and St. Sergius, 1981, pp. 67-87.

36. Macrides R. How the Byzantines Wrote History. Marjanović-Dušanić S., ed. Proceedings of the $23^{r d}$ International Congress of Byzantine Studies, Plenary Papers. Belgrade, National Committee for Byzantine Studies, 2016, pp. 257-263.

37. Mercati S.G. Collectanea Byzantina. Vol. 1. Bari, Acconcia Longo, Augusta, 1970. 712 p.

38. Munitiz J.A., ed. Nicephori Blemmydae Autobiographia sive Curriculum Vitae nec non Epistula universalior. Turnhout, Brepols, Leuven, University Press, $1984.156 \mathrm{p}$.

39. Schopen L., Bekker I., eds. Nicephori Gregorae Byzantina Historia. Vol. I. Bonnae, ed. Weberi, $1829.568 \mathrm{p}$.

40. Dieten I.A. van, ed. Nicetae Choniatae Historia. P. 1. Berlin, De Gruyter, 1975. CVIII, $656 \mathrm{p}$.

41. Dieten I.A. van, ed. Nicetae Choniatae Orationes et epistulae. Berlin, De Gruyter, 1972. XXIV, 279 p. (Corpus Fontium Historiae Byzantinae, 3).

42. Nicol D.M. The Byzantine Reaction to the Second Council of Lyons, 1261-1274. Runciman St., ed. Nicol D.M. Byzantium, Its Ecclesiastical History and Relations with the Western Word. Collected Studies. London, Variorum Reprints, 1972, pp. 113-146.

43. Dieten J.L. van, ed. Nikephoros Gregoras. Rhomäische Geschichte. Tl. 1. Stuttgart, Anton Hiersemann, 1973. VIII, 339p.

44. Simpson A., Efthymiades S., eds. Niketas Choniates. A Historian and a Writer. Geneva, La Pomme d'or, 2009.272 p.

45. Oikonomides N. Cinq actes inédits du patriarche Michel Autôreianos. Revue des Études Byzantines, 1967, vol. 25, pp. 113-145.

46. Trapp E. u. a., Hrsg. Prosopographisches Lexikon der Palaiologenzeit. Wien, Verlag der Österreichischen Akademie der Wissenschaften, 1976, Fasc. 1. 163 S. (in German).

47. Ševčenko I. Levels of Style in Byzantine Prose. XVI. Intern. Byzantinischenkongress. Akten. Tl. 1/1. Jahrbuch der Österreichischen Byzantinistik. Wien, 1981, Bd. 31/1,pp. 289-312.

48. Ševčenko I. Some Additional Remarks to the Report on Levels of Style. Jahrbuch der Österreichischen Byzantinistik, 1982, Bd. 32, pp. 220-229.

49. Simpson A.J. Before and After the Fall 1204: The Versions of Niketas Choniates' Historia. Dumbarton Oaks Papers, 2006, vol. 60, pp. 189-221.

50. Simpson A.J. Niketas Choniates: A Historiographical Study. Oxford, Oxford University Press, 2013. XVI, $372 \mathrm{p}$.
51. Kazhdan A.P. et al., eds. The Oxford Dictionary of Byzantium. Vol. 1. New York, Oxford, Oxford University Press, 1991. LIV, 728 p.

52. Kazhdan A.P. et al., eds. The Oxford Dictionary of Byzantium. Vol. 3. New York, Oxford, Oxford University Press, 1991. XXXIII, 1475-2232 p.

53. Festa N., ed. Theodori Ducae Lascaris Epistulae CCXVII. Firence, Tip. G. Carnesecchi e figli, 1898. XII, $414 \mathrm{p}$.

54. Tocci R., Hrsg. Theodori Scutariotae Chronica. Berlin, De Gruyter, 2015. VII, 545 S. (in German).

55. Tocci R. Zu Genese und Kompositionsvorgang der Synopsis Chronike des Theodoros Skutariotes. Byzantinische Zeitschrift, 2005, Bd. 98, Hft. 2, S. 551-568. (in German).

56. Tocci R. Bemerkungen zur Hand des Theodoros Skutariotes. Byzantinische Zeitschrift, 2006, Bd. 99, Hft. 1, S. 127-144. (in German).

57. Tocci R. Der unsichtbare Kaiser. Zum Bild Iustinianos' I. bei Theodoros Skutariotes. Kotzabassi S., Mavromatis L., Hrsg. Realia Byzantina. Berlin, New York, De Gruyter, 2009, S. 283-292. (in German).

58. Cuomo A., Trapp E., eds. Toward a Historical Sociolinguistic Poetics of Medieval Greek. Turnhout, Brepols Publ., 2018. VIII, 233 p.

59. Trapp E. The Language of the Byzantine Learned Literature. Dumbarton Oaks Papers, 2014, vol. 47, pp. 115-129.

60. Tudorie I.-A. Le Schism arsénite (1265-1310): entre Akribeia et Oikonomia. Zbornik radova Vizantološkog instituta [Collection of Works of Byzantine Institut], 2011, vol. 48, pp. 133-175.

61. Zafeiris K. Narrating the Past: Elements of littérarité in the Synopsis Chronike. Odorico P. et al., eds. L'écriture de la mémoire. La littérarité de l'historiographie. Actes du III colloque intern. «Ermēneia», Nicosie, 6-8 mai 2004. Paris, Diffusion De Boccard, 2006, pp. 33-47.

62. Zafeiris K. A Reappraisal of the Chronicle of Theodore of Kyzikos. Byzantinische Zeitschrift, 2010, Bd. 103, Hft. 2, S. 773-790.

63. Zafeiris K. The Issue of the Authorship of the Synopsis Chronike and Theodore Skoutariotes. Revue des Études byzantines, 2011, vol. 69, pp. 253-263.

64. Sathas K., ed. Anōnymou synopsis chronikē. Mesaionike bibliotheke. T. 7. Paris, Jean Maesonneuve, 1894. 680 б. (in Greek).

65. Gounarides P. To kinema ton Arseniaton 1261-1310. Ideologikes diamaches ten epoche ton proton Palaiologon [The Arsenite Movement 12611310. Ideological Conflicts in the Time of the Early Palaiologoi]. Athens, Domos, 1999. 245 б. (in Greek).

66. Karpozelos A. Byzantinoi istorikoi kai chronographoi, Tomos 4 (13 $13^{\text {os }}-15^{\text {os }}$ ai.) [Byzantine Historians and Chronicles, Vol IV $\left(13^{\text {th }}-15^{\text {th }} \mathrm{c}\right.$.)]. Athens, Kanake, 2015. 648 б. (in Greek). 


\section{ИСТОЧНИКОВЕДЕНИЕ ВИЗАНТИИ}

67. Lampakes S. Georgios Pachymeres: protekdikos kai dikaiophylaks, eisagogiko dokimio [George Pachymeres, Protekdikos and Dikaiophylax, Introductory Essay]. Athens, Hellenic National Research Foundation. Institute for Byzantine Research, 2004. 259 б. (in Greek).

68. Nikolopoulos P.G. Akolouthia anekdotos eis Arsenion patriarchen Konstantinoupoleos [An Unpublished Akolouthia for the Patriarch Arsenios of Constantinople]. Epeteris Etaireias Byzantinon Spoudon, 1977-1978, vol. 43, o. 406-461. (in Greek).
69. Nteebis T. $\bar{E}$ "Metaphrase" tes Chronikes Diegeseos tou Niketa Choniatou: didakt. diatribe [A "Metaphrase" of the Chronike Diegeseos of Niketas Choniates: Ph.D. Thesis]. Ioannina, 2004. 240 б. (in Greek).

70. Savvides A.G.K. Semeioma gia ton Byzantino chronikographo gia ton 13 ou aiona Theodoro Skoutariete kai te "Synopse chronike" [A Note on the $13^{\text {th }}$ Century Byzantine Chronicle Theodore Skoutariotes and "Synopsis Chronike"]. Byzantiaka, 2007, vol. 26, б. 221-231. (in Greek).

\section{Information about the Author}

Bojana D. Pavlović, PhD, Research Assistant, Institute for Byzantine Studies of the Serbian Academy of Sciences and Arts, Kneza Mihaila St., 35, 11000 Belgrade, Republic of Serbia, bojana.pavlovic85@gmail.com, https://orcid.org/0000-0002-4408-9110

\section{Информация об авторе}

Бойана Драган Павлович, $\mathrm{PhD}$, доктор исторических наук, научный ассистент Института византийских исследований, Сербская Академия наук и искусств, ул. Князя Михаила, 35, 11000 г. Белград, Республика Сербия, bojana.pavlovic85@gmail.com, https://orcid.org/0000-0002-4408-9110 